\title{
THERMODYNAMIC ASSESSMENT AND OPTIMIZATION OF A NOVEL TRIGENERATION ENERGY SYSTEM BASED ON SOLAR ENERGY AND MSW GASIFICATION USING ENERGY AND EXERGY CONCEPT
}

\author{
Amir Ghasemi ${ }^{1,{ }^{*}}$, Ali Akbar Shayesteh ${ }^{1}$, Amir Doustgani $^{2}$, Maryam Pazoki $^{1}$
}

\begin{abstract}
The current study aimed at delving into the thermodynamic study of a trigeneration cycle based on biomass fuel, combined with an Organic Rankine Cycle (ORC) and an absorption chiller. Biomass fuel is purely produced from Municipal Solid Waste (MSW). Energy and exergy analyses were carried out using the solar collector employing optimized characteristics to provide the required thermal energy at the ideal condition to utilizing in the high-temperature gasification process having hot steam. For supplying electricity, heating and cooling power, a Rankine cycle including a turbine, a heater, and a single effect absorption chiller was considered. To solar energy exploitation, a parabolic trough solar collector and hot steam gasifier were utilized. ORC can efficiently recover low-grade waste heat due to its excellent thermodynamic performance. Based on the examinations, the effects of critical thermodynamic parameters on the exergy efficiency and optimization of the trigeneration cycle and ORC with R134a, as working fluid, was conducted to achieve the system optimization design from thermodynamic aspect through Genetic Algorithm (GA). In this study, exergy destruction and its percentage in the power generation process were calculated as well. Results indicated that the studied system has the potential to generate $11.2 \mathrm{~kW}$ electricity, $17.4 \mathrm{~kW}$ heating power, $15.3 \mathrm{~kW}$ cooling power with the energy and exergy efficiencies of $64.3 \%$ and $52 \%$. It was also revealed that the output power of this system is fixed on the constant amount of $11.2 \mathrm{KW}$, which is obtained from the microturbine and ORC turbine. Additionally, it was demonstrated that the most exergy destructions are for gasifier, compressor, and combustor respectively, containing $47 \%, 26.3 \%$ and $14 \%$ of the destructions. Finally, the optimized performance of the system was determined using GA and exergy efficiency as an objective function. The optimized trigeneration energy system could yield the exergy efficiency of $4.4 \%$.
\end{abstract}

Keywords: Energy, Exergy, Gasification, Solar Energy, MSW, Optimization

\section{INTRODUCTION}

Nowadays, the use of non-conventional fuels and renewable energy instead of fossil fuels has been a significant challenge for the experts of the field throughout the world. Regarding this issue, it is established that biomass and wastes can be used as energy sources. Not only does MSW, which is used as a fuel in the gasification process, reduce $\mathrm{CO}_{2}$ blast, but also it can decrease the amount of waste and burial fission [1]. Lee et al.[2] presented the air gasification at the temperature ranging from $400^{\circ} \mathrm{C}$ to $800^{\circ} \mathrm{C}$ for syngas production. It should be stated that the problem that exists in this kind of gasification is the addition of nitrogen to the generated gas and dilution and reduction of the heating value. In an attempt, Vera et al.[3] solved this problem. They meticulously used steam gasification method in which nitrogen was removed. In the present article, biomass is used by steam gasification at a hypothetical temperature of $800^{\circ} \mathrm{C}$, for which the equation of gasification is as follows [2]:

$$
\mathrm{CH}_{x} \mathrm{O}_{y}+w \mathrm{H}_{2} \mathrm{O} \rightarrow a_{1} \mathrm{H}_{2}+a_{2} \mathrm{CO}+a_{3} \mathrm{CO}_{2}+a_{4} \mathrm{H}_{2} \mathrm{O}+a_{5} \mathrm{CH}_{4}
$$

Table 1 illustrates MSW intended percentage composition with $\mathrm{CH}_{1.46} \mathrm{O}_{0.69}$ a formula whose percentage composition of $\mathrm{O}, \mathrm{H}, \mathrm{C}$, coupled with high and low heat values.

This paper was recommended for publication in revised form by Regional Editor Erman Aslan 1School of Engineering, Department of Environment, University of Tehran, Tehran, Iran

2 Department of Chemical Engineering, College of Engineering, University of Zanjan, Zanjan, Iran ${ }^{*}$ E-mail address of corresponding author: amir_ghasemi@ut.ac.ir, amir.ghasemi.ut.ir@gmail.com Orcid id: 0000-0002-3910-6828, 0000-0002-6824-9457, 0000-0002-6137-1900, 0000-0003-1733-3365 Manuscript Received 17 September 2018, Accepted 20 December 2018 
Table 1. Component of MSW

\begin{tabular}{|c|c|c|c|}
\hline Property formula & $\mathbf{C ~ ( w ~ \% ) ~}$ & H (w \%) & O (w \%) \\
\hline \multirow{2}{*}{$\mathrm{CH}_{1.46} \mathrm{O}_{0.69}$} & 43.40 & 5.29 & 39.88 \\
\cline { 2 - 4 } & Humidity & LHV(MJ/kg) & HHV(MJ/kg) \\
\cline { 2 - 4 } & 14.93 & 13.98 & 15.58 \\
\hline
\end{tabular}

Various researchers have investigated the power generation plants exergy output and cogeneration cycles. Yipping poi et al.[4] for instance, analyzed energy and exergy and did optimizations for power generation plants. In another study, energy analysis and power generation plants optimization through GA were carried out by Chomra and Mago [5]. In this research, exergy, energy, power generation plants' exergy destruction and single objective optimization through GA were carried out. In their study, Klein [6] utilized EES for the optimization option. The turbine that was used in the present research was a microturbine. In all the researches that Laurence and Asherafi [7] conducted, the percentage of different components in the gas mixture, generated from the gasifier, did not have any impact on the performance of the turbine and only the temperature and pressure of the gas, caused by combustion, had considerable effects on the turbine performance. Pablo et al. [8] used the combination of the gasifier and solar collector for the first time to produce the syngas required in the combustor and further generate the power seamlessly. They provided the required temperature for generating steam in the gasification process using solar power. Al-Sulaiman et al.[9] analyzed energy and exergy of a solar driven trigeneration system. The study revealed that the maximum electrical-exergy efficiency for the solar mode, solar and storage mode and the storage mode were $7 \%, 3.5 \%$, and 3\% respectively. Alternatively, when trigeneration is employed, the exergy efficiency increases noticeably. Jiang-Jiang Wang et al. [10] examined an integrated CCHP system with biomass air gasification in order to reconnaissance the energy and exergy performance of the system. Destruction analyses of energy and exergy indicated that the largest destruction occurs in the gasification system, which accounts for more than $70 \%$ of the total energy and exergy losses. The annual performance showed that the suggested biomassfueled CCHP system decreases biomass consumption by $4 \%$ compared with the non-utilization of a heat recovery system for the high-temperature gas product. Huicochea et al.[11] used a trigeneration system consisting of a micro gas turbine and a double effect absorption chiller to theoretically analyze the thermodynamic performance of the suggested system, formed by a micro-turbine and a double-effect water/LiBr absorption chiller. The results illustrated that the system represents an alluring innovative option to use the energy from the micro-turbine exhaust gases for power generation, cooling, and heating, produced at the same time. Nadezhda et al.[12] analyzed a cogeneration system with biogas-fired engines based on energy and exergy evaluation. The purpose plant was established in Varna to utilize the local wastewater treatment unit as a source of methane production. The percentage of exergy annihilation within the system component is estimated using the exergy balance formulas. Moreover, the details of the thermodynamic performance of the system were reported in that paper. Moharamian et al.[13] compared three suggested combined cycle include: biomass co-fired CHP system, biomass post-fired and outwardly fired CHP system based on the thermoeconomic investigation. Also, the various working fluid was utilized in the organic Rankine cycle part of the system to indicate the best efficient fluid. The study revealed that the highest rate of energy and exergy productivity were displayed by post-fired CHP plant and lowest by the outwardly fired CHP plant. The overall highest and lowest costs of products were 16 \$/GJ and 5 \$/GJ for biomass post-fired CHP plant and outwardly fired CHP plant, respectively Koroglu et al.[14] investigated a marine power plant with ORC. About energy and exergy analysis of that system the optimum range of operation for the suggested plant was determined. Furthermore, the thermodynamic assessment illustrated the exergy destruction rare in each element of the system and recommended the condition to improve the overall efficiency of that energy system. Ghasemi et al.[15] evaluated an integrated CCHP plant based on thermodynamic aspects. In that survey, cooling, heating, freshly desalinated water, power were produced by two integrated renewable energy sources. The thermodynamic assessment revealed the significant source of irreversibility of the suggested system and the biomass burner had the highest rate of exergy distraction. Final outputs showed after optimization that suggested system will able to generate $802.5 \mathrm{KW}, 10391 \mathrm{KW}, 5658 \mathrm{KW}$ and $9.328 \mathrm{~kg} / \mathrm{s}$ power, heating, cooling, and desalinated water, respectively. Mehrpooya et al.[16] presented and analyzed a molten carbonate fuel cell (MCFC), Stirling engine and double effect $\mathrm{LiBr} / \mathrm{H}_{2} \mathrm{O}$ absorption chiller integrated with CCHP plant. Thermodynamic performance of that system calculated and results showed that overall energy and electrical 
efficiency of the purposed system were $71.77 \%$ and $42.28 \%$ respectively. Moreover, natural combustion of $\mathrm{CH}_{4}$ and $\mathrm{H}_{2}$ in the burners caused the primary sources of exergy annihilation in that power plant. Ghasemi et al.[17] suggested and investigated an integrated poly-generation energy system using solar and biomass as the renewable energy source for producing power, freshly desalinated water, biogas, cooling and heating. The thermodynamic and thermoeconomic rules applied to that system and resulted illustrated that the maintained cycle could generate 16.11kW, $28.94 \mathrm{~kW}, 23.41 \mathrm{~kW}, 8.8 \mathrm{~kg} / \mathrm{h}, 0.02 \mathrm{~m}$ 3/h, electric power, heating, cooling, desalinated water, and liquated natural gas, respectively. Initial performance of plant showed the energy and exergy efficiencies of 46.8 $\%, 11.2 \%$, and product cost rate $15.16 \$ / \mathrm{h}$. After using the genetic algorithm as a multi-objective optimizer, overall exergy efficiency improved to $9.9 \%$ and the total product cost rate of the system decreased to $13.32 \$ / \mathrm{h}$.

\section{MATERIALS AND METHODS SYSTEM DESCRIPTION}

Power generation cycle is depicted in Figure 1. This cycle is composed of a gaseous micro-turbine, a compressor to supply air for the gas combustion, a gasifier to generate syngas from MSW which is utilized as gaseous fuel in the combustor, a solar collector to generate superheated steam at the sutaible and accessible condition and finally two heat exchanger units, one to absorb the heat of the gas, generated from the turbine, and the other one for cooling the syngas, and a pump.

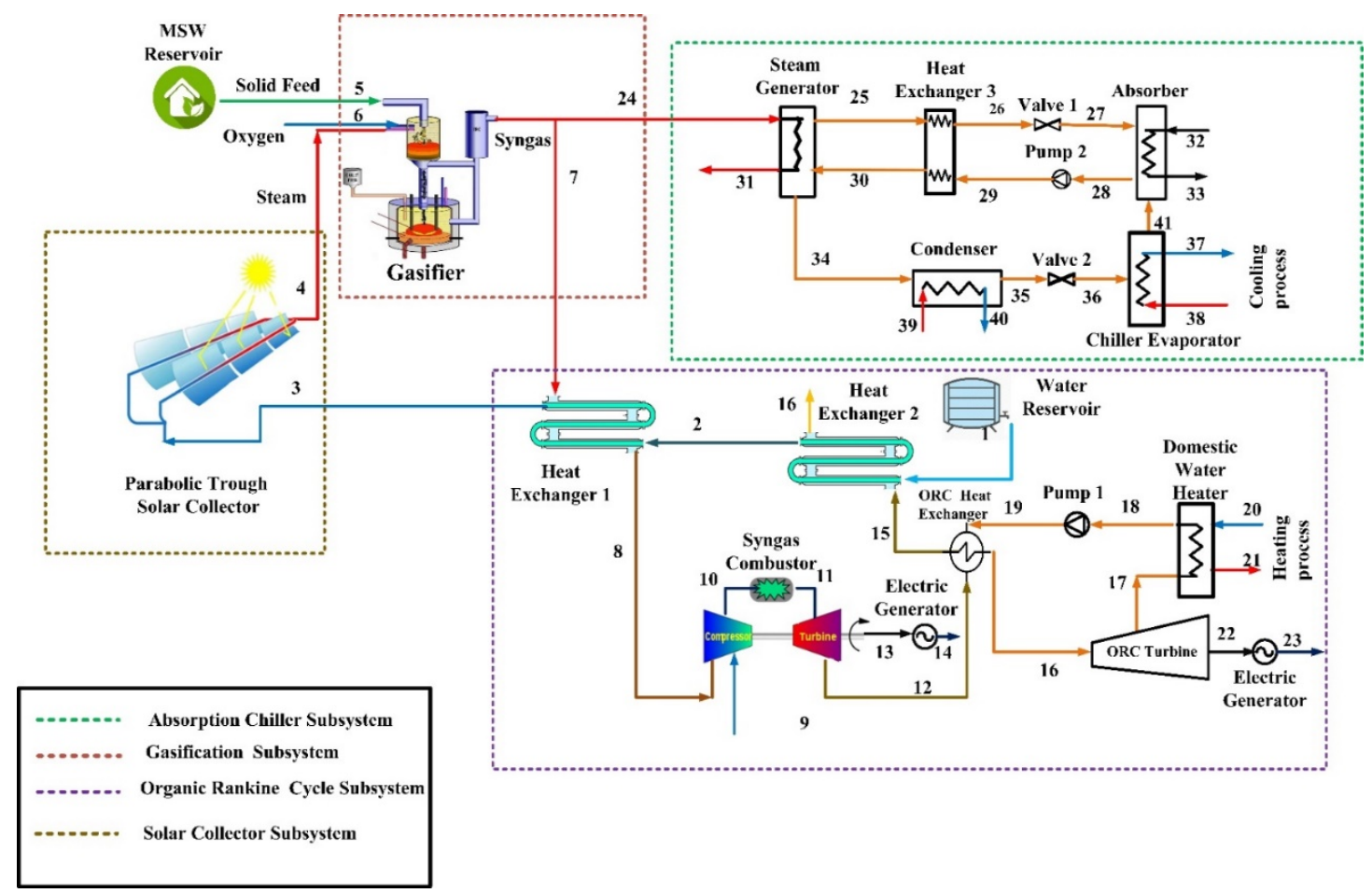

Figure 1. Trigeneration energy system

This cycle is contained four subsystems as it clears in Figure 1.They were separated into absorption chiller, gasification, organic Rankine cycle and, solar collector subsystems. MSW with the optimized content with stream number 5 and hot steam with stream number 4, generated by the solar collector, enter the gasifier in gasification subsystem. They react based on equation 1 , and the part of output syngas with stream number 7 enters the heat exchanger 1 to be cooled and made ready to enter the compressor with stream number 8 . This output syngas uses its heat capacity to warm the water entering with stream number 3 the solar collector. After the syngas is cooled, the compressor increases its pressure. During this process, syngas is combined with the incoming air with stream number 9 from a compressor in the combustor, and consequently, the combustion takes place. Then, a hot gas which has high pressure with stream number 11 enters the turbine and generates power. The compressor consumes the amount of this power. 
Moreover, another part of syngas enters the absorption chiller with stream number 24. Hot syngas passes through the vapor generator and enters a single-effect absorption cycle which uses $\mathrm{LiBr}-\mathrm{H}_{2} \mathrm{O}$ to provide cooling. At the next stage, low-pressure gas again enters the ORC heat exchanger with stream number 12, and its heat capacity is transferred to R134a for power generation with ORC microturbine with stream number 16 . The heat exchanger 2 is the final element which uses the maximum heat capacity to feed water heating. Finally, the process is completed.

\section{THERMOYNAMIC MODELING}

Mass and energy conservation laws are used in order to simulate the system. Exergy is the maximum amount of work obtained from the given form of exergy employing environmental parameters as the reference state.

Taking the first and second thermodynamic laws into consideration, some assumed input, energy, and exergy balance have been shown as follows:

- The gas produced through gasification does not require any treatment and contains no suspended solids.

- The gas behavior is assumed to be ideal.

- The changes in kinetic and potential energy and exergy terms are negligible.

- Expansion and density are assumed to be isotropic.

- The condition is steady-state.

- The reference-environment state's temperature and pressure are $\mathrm{T}_{0}=298 \mathrm{~K}$ and $\mathrm{P}_{0}=100 \mathrm{KPa}$, respectively.

- $\quad$ LHV for MSW is $10500 \mathrm{~kJ} / \mathrm{kg}$.

The exergy balance for a control volume includes the exergy of heat, mass, and workflows, transforming across the boundaries as well as the exergy destroyed within the control volume. Neglecting the kinetic and potential effects, the exergy of mass flow is divided into chemical and physical exergy parts. Exergy balance for a control volume is formulated as follow [18],[19]:

$$
\begin{gathered}
\dot{E} x_{D}=\sum_{k}\left(1-\frac{T_{0}}{T_{k}}\right) \dot{Q}_{k}-\dot{W}+\left(\sum_{k} \dot{E} x_{k}^{p h, c h}\right)_{\text {in }}-\left(\sum_{k} \dot{E} x_{k}^{p h, c h}\right)_{\text {out }} \\
\dot{E} x^{p h}=\dot{m}\left[\left(h-h_{0}\right)-T_{0}\left(s-s_{0}\right)\right] \\
\dot{E} x^{c h}=\sum_{k=1}^{n} x_{k} e x_{c h}^{k}+R T_{0}+\sum_{k=1}^{n} e x_{k} \ln e x_{k}
\end{gathered}
$$

For a better classification, three subsystems have been taken into account for the trigeneration energy system. Furthermore, thermodynamic modeling of the subsystems has been conducted as below:

\section{PARABOLIC TROUGH COLLECTOR SUB-SYSTEM}

Parabolic Trough Collectors (PTCs) have been used to collect solar energy as one of the energy sources of the trigeneration energy system. Due to Therminol vp-1 oil is the heat transfer properties and it has the hightemperature stability, it is selected to be used as working fluid in the solar collector. Governing equation of PTC subsystem can be composed as follows [20]:

$$
\dot{E}_{s}=\dot{m}_{4} C_{p}\left(T_{4}-T_{3}\right)=A_{a} F_{R}\left(S-\frac{A_{r}}{A_{a}} U_{L}\left(T_{4}-T_{0}\right)\right.
$$

Here, $F_{R}$ is the heat removal factor, $S$ is the heat absorbed by the receiver, $A_{r}$ is the receiver area, $A_{a}$ is the aperture area, and $U_{\mathrm{L}}$ is the solar collector overall heat loss coefficient [21]. 


$$
\begin{gathered}
E \dot{X}_{D, P T C}=E \dot{x}_{s}-\dot{m}_{4}\left(e x_{4}-e x_{3}\right) \\
E \dot{x}_{s}=A_{\text {coll }} \times G_{t} \times\left[1+\frac{1}{3}\left(\frac{T_{0}}{T_{s}}\right)^{4}-\frac{4}{3}\left(\frac{T_{0}}{T_{s}}\right)\right]
\end{gathered}
$$

\section{RANKINE CYCLE SUB-SYSTEM}

Turbine:

$$
\begin{gathered}
\dot{W}_{\text {turb }}=\dot{m}_{11}\left(h_{11}-h_{12}\right) \\
\eta_{\text {is,turb }}=\frac{\dot{W}_{\text {turb }}}{\dot{W}_{\text {is,turb }}} \\
E \dot{x}_{D, \text { turb }}=\dot{m}_{11}\left(e x_{11}-e x_{12}\right)-\dot{W}_{\text {turb }}
\end{gathered}
$$

Compressor:

$$
\begin{gathered}
\dot{W}_{\text {Comp-Air }}=\dot{m}_{9}\left(h_{9}-h_{10}\right) \\
\dot{W}_{\text {Comp-Syngas }}=\dot{m}_{8}\left(h_{10}-h_{8}\right) \\
\dot{W}_{\text {Comp }}=\dot{W}_{\text {Comp-Air }}+\dot{W}_{\text {Comp-Syngas }} \\
E \dot{X}_{D, \text { Comp }}=\dot{m}_{9} e x_{9}+\dot{m}_{8} e x_{8}+\dot{W}_{\text {Comp }}-\dot{m}_{10} e x_{10}
\end{gathered}
$$

Syngas Combustor:

$$
\begin{gathered}
\dot{m}_{10} h_{10}+\dot{Q}_{\text {Comb }}=\dot{m}_{11} e x_{11} \\
E x_{\dot{Q}_{\text {Comb }}}=q_{\text {Comb }}\left(1-\left(\frac{T_{0}}{600}\right)\right) \\
E \dot{X}_{D, \text { Comb }}=\dot{m}_{10} e x_{10}-\dot{m}_{11} e x_{11}+E \dot{X}_{Q_{C o m b}}
\end{gathered}
$$

Domestic Water Heater:

$$
\begin{gathered}
E \dot{x}_{D W H}=\dot{m}_{20}\left(h_{21}-h_{20}\right) \\
\dot{E} x_{D W H}=\dot{m}_{20}\left(e x_{21}-e x_{20}\right) \\
E \dot{x}_{D, D W H}=\dot{m}_{17}\left(e x_{17}-e x_{18}\right)-\dot{m}_{20}\left(e x_{21}-e x_{20}\right)
\end{gathered}
$$

Pump1:

$$
\begin{gathered}
\dot{W}_{\text {Pump } 1, \text { is }}=\dot{m}_{18}\left[v_{18}\left(P_{19}-P_{18}\right)\right] \\
\dot{W}_{\text {Pump } 1}=\dot{m}_{18}\left(h_{19}-h_{18}\right) \\
E \dot{X}_{D, \text { Pump } 1}=\dot{W}_{\text {Pump } 1}-\dot{m}_{18}\left(e x_{19}-e X_{18}\right)
\end{gathered}
$$


Heat Exchanger1:

$$
\begin{gathered}
\dot{m}_{7}\left(h_{7}-h_{8}\right)=\dot{m}_{2}\left(h_{3}-h_{2}\right) \\
\dot{Q}_{H X, 1}=\dot{m}_{3}\left(h_{3}-h_{2}\right) \\
\dot{Q}_{H X, 1}=U_{H X, 1}\left(A_{H X, 1}\right)\left(L_{H X, 1}\right) \\
L_{H X, 1}=\frac{\left(T_{7}-T_{2}\right)-\left(T_{8}-T_{3}\right)}{\operatorname{Ln}\left(\frac{\left(T_{7}-T_{2}\right)}{\left(T_{8}-T_{3}\right)}\right)} \\
E \dot{x}_{D, H X, 1}=\left[\dot{m}_{7}\left(e x_{7}\right)-\dot{m}_{8}\left(e x_{8}\right)\right]-\left[\dot{m}_{3}\left(e x_{3}\right)-\dot{m}_{2}\left(e x_{2}\right)\right]
\end{gathered}
$$

Electric Generator:

$$
\begin{gathered}
\dot{W}_{\text {net }}\left(\eta_{E G}\right)=\dot{W}_{\text {Elec }} \\
e X_{13}=\dot{W}_{\text {net }} \\
e X_{14}=\dot{W}_{\text {Elec }} \\
E \dot{x}_{D, E G}=\left(e x_{13}-e x_{14}\right)
\end{gathered}
$$

Expansion valve1:

$$
\begin{gathered}
h_{27}=h_{26} \\
\dot{m}_{27}=\dot{m}_{26} \\
E \dot{X}_{D, E G}=\dot{m}_{26}\left(e x_{26}-e x_{27}\right)
\end{gathered}
$$

Absorption Chiller:

$$
\begin{gathered}
\dot{m}_{24}\left(h_{24}-h_{31}\right)+\dot{W}_{\text {pump } 2}=\dot{m}_{39}\left(h_{39}-h_{40}\right)+\dot{m}_{33}\left(h_{33}-h_{32}\right)+\dot{m}_{38}\left(h_{38}-h_{37}\right) \\
\dot{E}_{\text {Evap }}=\dot{m}_{38}\left(h_{38}-h_{37}\right) \\
E \dot{x}_{D, A C}=\dot{m}_{24}\left(e x_{24}-e x_{31}\right)+\dot{W}_{\text {pump } 2}-\dot{m}_{38}\left(h_{38}-h_{37}\right)
\end{gathered}
$$

\section{GASIFICATION SUB-SYSTEM}

$$
H H V_{\text {Fuel }}=0.3491 z_{c}+1.1783 z_{H}-0.1034 z_{O}-0.0151 z_{N}+0.1005 z_{S}-0.021 z_{A}
$$

In this equation, $H H V_{\text {Fuel }}$ is the higher heating value of the fuel in $\mathrm{MJ} / \mathrm{kg}$ and $z_{A}$, $Z_{H}, Z_{N}, Z_{O}$ and $Z_{S}$ the weight fractions of ashes, carbon, hydrogen, nitrogen, oxygen, and Sulphur (w.t \% dry) respectively. 


$$
\begin{gathered}
e x_{\text {Ch, Fuel }}=\beta \cdot H H V_{\text {Fuel }} \\
\beta=1.0438+0.0158 \cdot \frac{H}{C}+0.0813 \frac{O}{C} \quad \text { for }: \frac{O}{C} \leq 0.5 \\
\beta=\frac{1.0414+.0177 \cdot \frac{H}{C}-0.3328 \cdot \frac{O}{C} \cdot\left[1+0.0537 \cdot \frac{H}{C}\right]}{1-0.4021 \cdot \frac{O}{C}} \quad \text { for }: 0.5 \leq \frac{O}{C} \leq 2
\end{gathered}
$$

In these equations, $H H V_{\text {Fuel }}$ is the higher heating value of fuel in $\mathrm{MJ} / \mathrm{kg}, \quad e X_{C h, \text { Fuel }}$ the chemical exergy of fuel in $\mathrm{MJ} / \mathrm{kg}, \quad \beta$ the ratio of chemical exergy and higher heating value of fuel and $\mathrm{C}, \mathrm{H}, \mathrm{O}$ the mole fractions of carbon, hydrogen and oxygen in the fuel, respectively [22].

$$
\begin{gathered}
\dot{E}_{\text {Gasfier }}=\dot{m}_{M S W}\left(H H V_{M S W}\right)+\dot{m}_{O X}\left(h_{O X}\right)+\dot{m}_{4}\left(h_{4}\right)-\left(\dot{m}_{7}+\dot{m}_{24}\right)\left[\left(h_{7}+h_{24}\right)\right] \\
E \dot{x}_{D, \text { Gasfier }}=\dot{m}_{M S W}\left(e x_{c h, \text { Fuel }}\right)+\dot{m}_{O X}\left(e x_{O X}\right)+\dot{m}_{4}\left(e x_{4}\right)+\left(\dot{m}_{7}+\dot{m}_{24}\right)\left[\left(e x_{7}+e x_{24}\right)\right]
\end{gathered}
$$

\section{PERFORMANCE ASSESSMENT}

In order to assess the energetic and exergetic performance of the aimed energy system, energy efficiency and exergy efficiency are selected as the performance criteria and are defined as below:

Energy efficiency [23]:

$$
\begin{gathered}
\eta_{\text {en }}=\frac{\dot{E}_{\text {Output }}}{\dot{E}_{\text {Input }}} \\
\dot{E}_{\text {Input }}=\dot{E}_{\text {Gasifire }}+\dot{E}_{s} \\
\dot{E}_{\text {Output }}=\dot{W}_{\text {Network }}+\dot{E}_{\text {Colling }}+\dot{E}_{\text {Heating }} \\
\dot{W}_{\text {Network }}=\dot{W}_{\text {turb }}\left(\eta_{\text {Gen }}\right)+\dot{W}_{\text {ORC,turb }}\left(\eta_{\text {Gen }}\right)-\left(\dot{W}_{\text {pump } 1}+\dot{W}_{\text {pump } 2}+\dot{W}_{\text {Comp }}\right)
\end{gathered}
$$

Exergy efficiency:

$$
\begin{gathered}
\dot{E} x_{f}=\dot{E} x_{\text {Gasfier }}+\dot{E} x_{s} \\
\dot{E} x_{p}=\dot{W}_{\text {Network }}+\dot{E} x_{\text {Heating }}+\dot{E} x_{\text {Colling }}
\end{gathered}
$$

\section{OPTIMIZATION}

Optimization plays an undeniable role in many engineering designs. An optimization modeling can result in an optimum design for which it is not necessary to consider all possible cases and their impacts. In other words, ensuring an optimum case, optimization can decrease simulation time. From the thermodynamic point of view [24], the actual performance of a processor energy system can be assessed by the exergetic efficiency. 


\section{DEFINITION OF OBJECTIVE FUNCTION}

In this paper, the optimization of the cycle was performed using exergy efficiency. Exergy efficiency which is to be maximized is regarded as the objective function of the process. In this analysis, the objective function can be demonstrated as follow [25]:

$$
\eta_{e x}=\frac{\dot{E} x_{p}}{\dot{E} x_{f}}
$$

Concerning the optimization problem, some parameters were included in a way to maximize the exergy efficiency, and consequently, the output work rate of the product was chosen.

\section{SENSITIVITY ANALYSIS}

Sensitivity analysis as a general concept attempting to quantify the variations of an output parameter of a system regarding changes imposed on some important input parameters [26]. A comprehensive sensitivity analysis is conducted to check the impact of the variation of significant factors on total exergy efficiency. The most important factors which influence total exergy efficiency include air compressor pressure ratio, gas turbine inlet temperature, gasifier inlet steam temperature, and combustor inlet temperature. In this study, the decision variables are the most critical factors which affect total exergy efficiency. Each decision variables usually are required to be within a reasonable range as listed in Table 2 .

Table 2. The design parameters and their range of variation for the optimization procedure

\begin{tabular}{|l|c|c|}
\hline \multicolumn{1}{|c|}{ Case studies } & From & To \\
\hline Air compressor pressure ratio & 8 & 24 \\
\hline Gasifier inlet steam temperature (K) & 600 & 1200 \\
\hline Combustor inlet temperature (K) & 632 & 670 \\
\hline Gas turbine inlet temperature (K) & 692 & 550 \\
\hline
\end{tabular}

\section{GENETIC ALGORITHM (GA)}

The genetic algorithm (GA) is defined as a method that can be employed to solve constrained and unconstrained optimization problems based on natural selection, the process which drives biological evolution. Passing through the system constraints, exergy analysis, and exergoeconomic formulations were utilized to assess the objective function for each trial. Then, parent selection was conducted, bearing in mind that each had the same probability of being chosen [27]. $N_{p}$ was used for the size of the generated population. Therefore, $N_{P}$ numbers of parents entered the reproduction step which generates $N_{P}$ offspring through a crossover strategy in which the decision variable values of the offspring fall in a range defined by the decision variable values of the parents. Some of the off-springs were also produced by adding a Gaussian random variable $(\mathrm{N})$ with zero mean and a standard deviation proportional to the scaled cost value of the parent trial solution, i.e.,

$$
P_{g, i}^{\prime}=P_{g, i}+N\left(0, \sigma_{i}^{2}\right)
$$

The standard deviation $\sigma_{i}$ demonstrates the range over which the offspring is produced around the parent trial solution and is calculated by:

$$
\sigma_{i}^{2}=\varphi \frac{f\left(\bar{P}_{i}\right)}{f\left(\bar{P}_{\min }\right)}
$$

where $f\left(\bar{P}_{\min }\right)$ is the minimum value of the objective function among the $\mathrm{N}_{\mathrm{p}}$ trial solution, $f\left(\overline{P_{i}}\right)$ is the objective function value associated with the trial vector $\left(\overline{P_{i}}\right)$ and $\varphi$ is a scaling factor. These off-springs, i $=1,2, \ldots, \mathrm{NP}$ and their parents, $\mathrm{i}=1,2, \ldots, \mathrm{N}_{\mathrm{P}}$ form a set of $2 \mathrm{~N}_{\mathrm{P}}$ trial solutions and contend for survival within the competing pool. Having completed, the $2 \mathrm{~N}_{\mathrm{p}}$ trial solutions, consisting of the parents and the offspring, are ranked in 
descending order of the score. The first $\mathrm{N}_{\mathrm{P}}$ trial solutions survive and are subsequently transcribed along with their objective functions $f\left(\bar{P}_{i}\right)$ into the survivor set as the basis of the next generation. Eventually, the number of generations elapsed and the established maximum number of generations were compared with each other. Should the termination condition be met, the process stopped. Otherwise, the surviving solutions became the starting population for the next generation. In this study, in the first generation, 100 vectors $\bar{P}_{i}=\left[T_{11}, R_{A C}, T_{4}, T_{g}\right]$ were randomly generated within the operating range. Performance of the system with each vector was evaluated. The vector having the best system performance was stored for future comparison. The algorithm selected a group of vectors in the current generation, called parents that had better objective function values for the next generation (second generation). These parents were modified using in the equation (50) to generate the off-springs. The performance of the off-springs and the parent vectors were compared in order to select the best vector in the generation. The process of selecting parents and then generating the off-springs was repeated until the specified number of generations was achieved [28].

\section{RESULT AND DISCUSSION}

Thermodynamic analyses are run through developing codes in Engineering Equation Solver Software [6] using input data is shown in Table 4. Input data is the initial parameters that used to model the thermodynamically cycles. All of the data in table 4 was extracted from other similar articles and technical reports of components like collectors, turbines, evaporators, etc.

Table 4. Input data for modeling of the Trigeneration energy system

\begin{tabular}{|l|c|}
\hline \multicolumn{1}{|c|}{ Parameters } & Value \\
\hline Collector outlet temperature, $T_{4}\left({ }^{\circ} \mathrm{C}\right)$ & 454 \\
\hline Turbine inlet temperature, $T_{8}\left({ }^{\circ} \mathrm{C}\right)$ & 365 \\
\hline Turbine inlet pressure, $P_{8}(\mathrm{kPa})$ & 15000 \\
\hline Temperature difference of chiller evaporator, $\Delta T_{\text {eva }}\left({ }^{\circ} \mathrm{C}\right)$ & 15 \\
\hline Temperature difference of heater, $\Delta T_{H}\left({ }^{\circ} \mathrm{C}\right)$ & 20 \\
\hline Temperature of the syngas of gasification, $T_{24}\left({ }^{\circ} \mathrm{C}\right)$ & 1500 \\
\hline Evaporator temperature, $T_{\text {eva }}\left({ }^{\circ} \mathrm{C}\right)$ & 15 \\
\hline LHV of MSW, $\mathrm{LHV} V_{\mathrm{MSW}}(\mathrm{Mj} / \mathrm{kg})$ & 13.98 \\
\hline The compression ratio of the compressor, $\frac{P_{12}}{P_{11}}(-)$ & 10 \\
\hline
\end{tabular}

Table 5 illustrates the outputs of results of modeling for each state of the system (Figure 1). Specific enthalpy, entropy, and exergy of each state was utilized to evaluate exergy destructions of elements. Moreover, calculation of exergy and energy efficiencies of the proposed trigeneration energy system is based on this information. 
Table 5. Results of thermodynamic modeling of trigeneration energy system

\begin{tabular}{|c|c|c|c|c|c|}
\hline $\begin{array}{c}\text { State } \\
\text { no. }\end{array}$ & $\begin{array}{c}\text { Temperature, } \\
\text { (K) }\end{array}$ & $\begin{array}{c}\text { Pressure, } \\
(\mathrm{kPa})\end{array}$ & $\begin{array}{c}\text { Specific enthalpy, } \\
(\mathrm{kJ} / \mathrm{kg})\end{array}$ & $\begin{array}{l}\text { Specific entropy, } \\
(\mathrm{kJ} / \mathrm{kg} . \mathrm{K})\end{array}$ & $\begin{array}{l}\text { Specific exergy, } \\
(\mathrm{kJ} / \mathrm{kg})\end{array}$ \\
\hline 0 & 298 & 101.3 & 104.1 & 0.37 & 0 \\
\hline 1 & 298 & 101.3 & 104.3 & 0.37 & 0 \\
\hline 2 & 420 & 101.3 & 2776 & 8.66 & 160.4 \\
\hline 3 & 470 & 101.3 & 2873 & 8.66 & 185.9 \\
\hline 4 & 727 & 2500 & 3991 & 10.45 & 704.4 \\
\hline 5 & 298.2 & 100 & 3156 & 0.34 & 27960 \\
\hline 6 & 600 & 2000 & 2637 & 5.14 & 1361 \\
\hline 7 & 480 & 2000 & 2170 & 4.56 & 1026 \\
\hline 8 & 650 & 20000 & 3174 & 8.84 & 1910 \\
\hline 9 & 298.2 & 100 & 298.6 & 0.5 & 0 \\
\hline 10 & 609 & 20000 & 616.8 & 5.56 & 924 \\
\hline 11 & 680 & 20000 & 3458 & 5.61 & 2875 \\
\hline 12 & 540 & 2000 & 2132 & 4.81 & 1804 \\
\hline 13 & - & - & - & - & - \\
\hline 14 & - & - & - & - & - \\
\hline 15 & 400 & 12000 & 575.2 & 2.72 & 21.82 \\
\hline 16 & 266.6 & 800 & 185.2 & 2.4 & 8.94 \\
\hline 17 & 266.6 & 800 & 190.5 & 0.94 & 13.55 \\
\hline 18 & 298.6 & 12000 & 298.4 & 0.95 & 13.7 \\
\hline 19 & 298.6 & 101.3 & 270.3 & 0.87 & 0.76 \\
\hline 20 & 270 & 101.3 & 251.4 & 0.91 & 1.2 \\
\hline 21 & 332 & 150 & 125.5 & 0.43 & 1393 \\
\hline 22 & - & - & - & - & - \\
\hline 23 & - & - & - & - & - \\
\hline 24 & 360.2 & 101.3 & 361.2 & 5.886 & 5.729 \\
\hline 25 & 353 & 7.42 & 185.6 & 0.19 & 287.6 \\
\hline 26 & 318.6 & 7.42 & 123.2 & 0.2 & 287.7 \\
\hline 27 & 308.6 & 0.68 & 123.2 & 0.2 & 569.7 \\
\hline 28 & 307 & 0.6812 & 93.07 & 0.2 & 283.6 \\
\hline 29 & 307 & 7.42 & 159 & 0.39 & 289.5 \\
\hline 30 & 340.6 & 7.42 & 159 & 0.4 & 287.7 \\
\hline 31 & 298 & 101.3 & 298.6 & 5.7 & 0.02 \\
\hline 32 & 308 & 101.3 & 146.7 & 5.6 & - \\
\hline 33 & 298 & 101.3 & 104.8 & 0.37 & - \\
\hline 34 & 353 & 7.42 & 2649 & 8.48 & 126.6 \\
\hline 35 & 313.1 & 40.11 & 168 & 0.5737 & 1.486 \\
\hline 36 & 274.5 & 0.6812 & 168 & 0.6116 & 9.795 \\
\hline 37 & - & - & - & - & - \\
\hline 38 & - & - & - & - & - \\
\hline 39 & 298 & 101.3 & 104.8 & 0.37 & - \\
\hline 40 & 303 & 100 & 125.8 & 0.43 & - \\
\hline 41 & 274.5 & 0.6812 & 2503 & 9.114 & 208.3 \\
\hline
\end{tabular}


The consequential step in improving the thermodynamic performance of an energy system is the recognition of exergy destruction sources and the attempt to eliminate them; therefore, exergy destruction rate of the subsystem of the trigeneration energy system is assessed and illustrated in Figure 2.

Figure 2 illustrates the overall exergy destruction rate of all components. As depicted in Figure 2 and the exergy analysis, for the operating conditions considered, the essential exergy destruction is caused by the gasifier. This result can be dealt with the significant irreversibility associated with the chemical reaction and heat transfer. The heat transfer between two sources of energy has proven as one of enormous reason for energy and exergy irreversibility. Moreover, because of changing between molecular bonds in the component at chemical reaction such as combustion, gasification and decomposition reactions most of the exergy annihilates in this kinds of process. As discussed in the related literature, a significant source of the exergy destruction can be a chemical reaction leading to more irreversibility [29]. As it is evident in Figure 2 compressor has the second rank of exergy destruction in the proposed system in comparison to other parts of the systems. It occurs because the vast difference at pressure factor between input and output streams in the compressor. Generally, any sodden shocks that are occurred in streams can make exergy destruction, and as it is clear, there is a high difference (100 and $2000 \mathrm{kPa})$ between stream number 9 and 10 that is the reason of exergy destruction. Finally, the third most exergy destruction is happened in the combustor and based on previous explanation due to the chemical irreversible reaction between compressed air, syngas that produces exhausted hot gas create exergy destruction in that component. The exergy destruction in ORC condenser. The exergy destruction of ORC condenser, ORC pump, absorption chiller, and ORC turbine are negligible are also presented in Figure 2 [30].

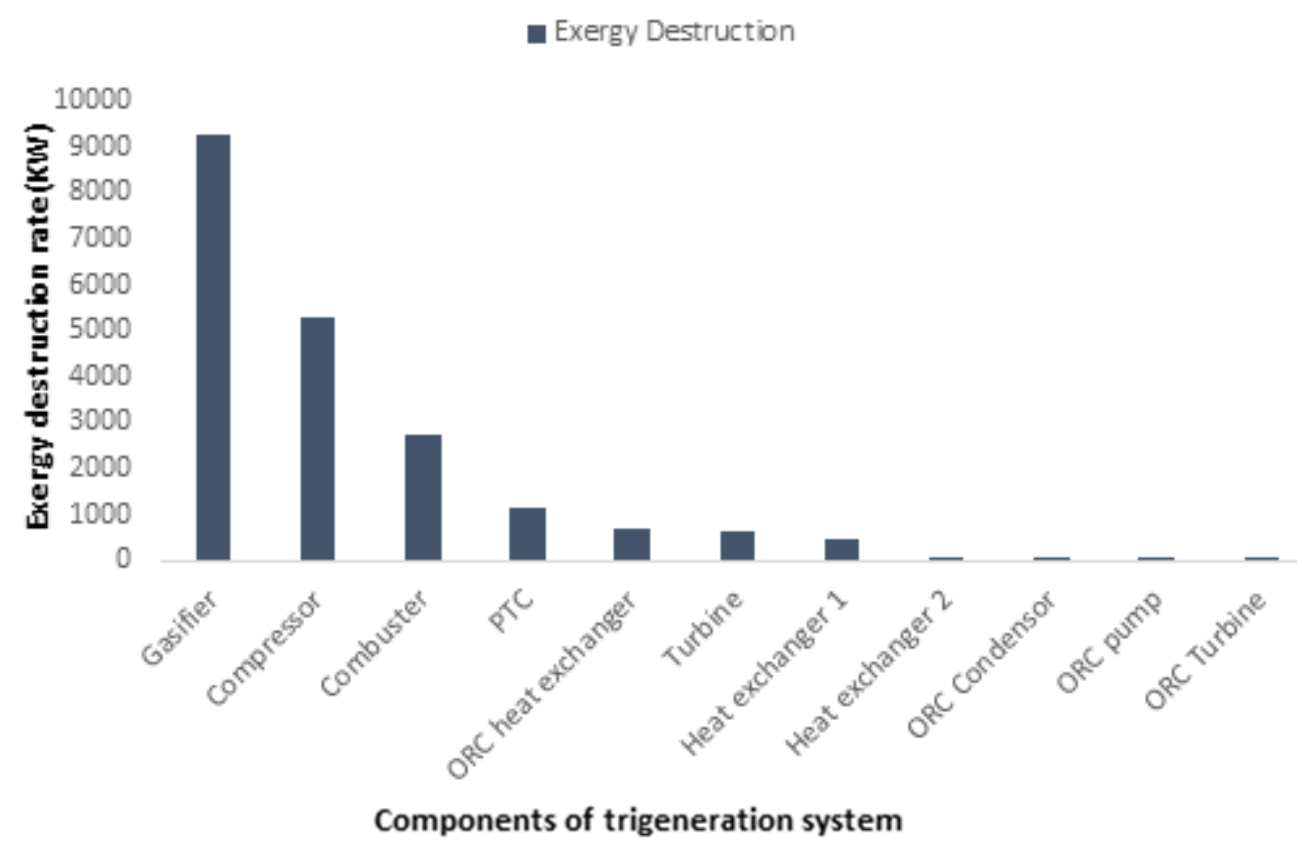

Figure 2. Exergy destruction ratios

According to input data and formulas presented earlier, the first and second laws of thermodynamics were applied to all components of the proposed system. The performance indices of the system such as energy and exergy efficiencies, required MSW mass flow rate, required collector area, heating and cooling loads, exergy of heating and cooling loads and power to the network be achieved and are showed in Table 6 . This information is based on initial input data( Table4), and it indicates the inner potential of aimed trigeneration system. In order to improve the performance of the system, genetic algorithm is used to make a change in sensitive parameters of the system due to reach the best point of them. In those points, both of the exergy and the energy efficiencies of the trigeneration energy system are optimized. 
Table 6. Thermodynamic performance of Trigeneration energy system

\begin{tabular}{|l|c|}
\hline \multicolumn{1}{|c|}{ Parameters } & Value \\
\hline Energy efficiency, $\eta_{\text {en }}(\%)$ & 64.3 \\
\hline Exergy efficiency, $\eta_{\text {ex }}(\%)$ & 52 \\
\hline Required MSW mass flow rate, $\dot{m}_{\text {bio }}(\mathrm{kg} / \mathrm{h})$ & 2.1 \\
\hline Required collector area, $A_{\text {coll }}\left(\mathrm{m}^{2}\right)$ & 504.2 \\
\hline Heating load, $\dot{E}_{H}(\mathrm{~kW})$ & 17.4 \\
\hline Cooling load, $\dot{E}_{\text {eva } 2}(\mathrm{~kW})$ & 15.3 \\
\hline Exergy of heating load, $\dot{E} x_{H}(\mathrm{~kW})$ & 3.2 \\
\hline Exergy of the cooling load, $\dot{E} x_{\text {eva }}(\mathrm{kW})$ & 0.13 \\
\hline Power to network, $\dot{W}_{\text {network }}(\mathrm{kW})$ & 11.2 \\
\hline
\end{tabular}

\section{OPTIMIZATION RESULTS}

After detecting the sensitive parameters of the aimed energy system, the effect of compressor pressure ratio on exergy efficiency was found as one of the sensitive points of the system. Figure 3 shows the effect of the air compressor pressure ratio variation on the exergy efficiency. It is clear that as compressor pressure ratio increases, exergy efficiency decreases and this change in exergy efficiency are occurred because of the compressor consumed the part of the produced power to increasing pressure of the inlet air to improve the performance of combustion process at the combustor chamber. Considering the mentioned explanation for exergy efficiency, the trend attained for exergy efficiency variation is expected according to the efficiency definition. The optimum point for this case is $R_{A c}=8$, so exergy efficiency is equal to $52.08 \%$.

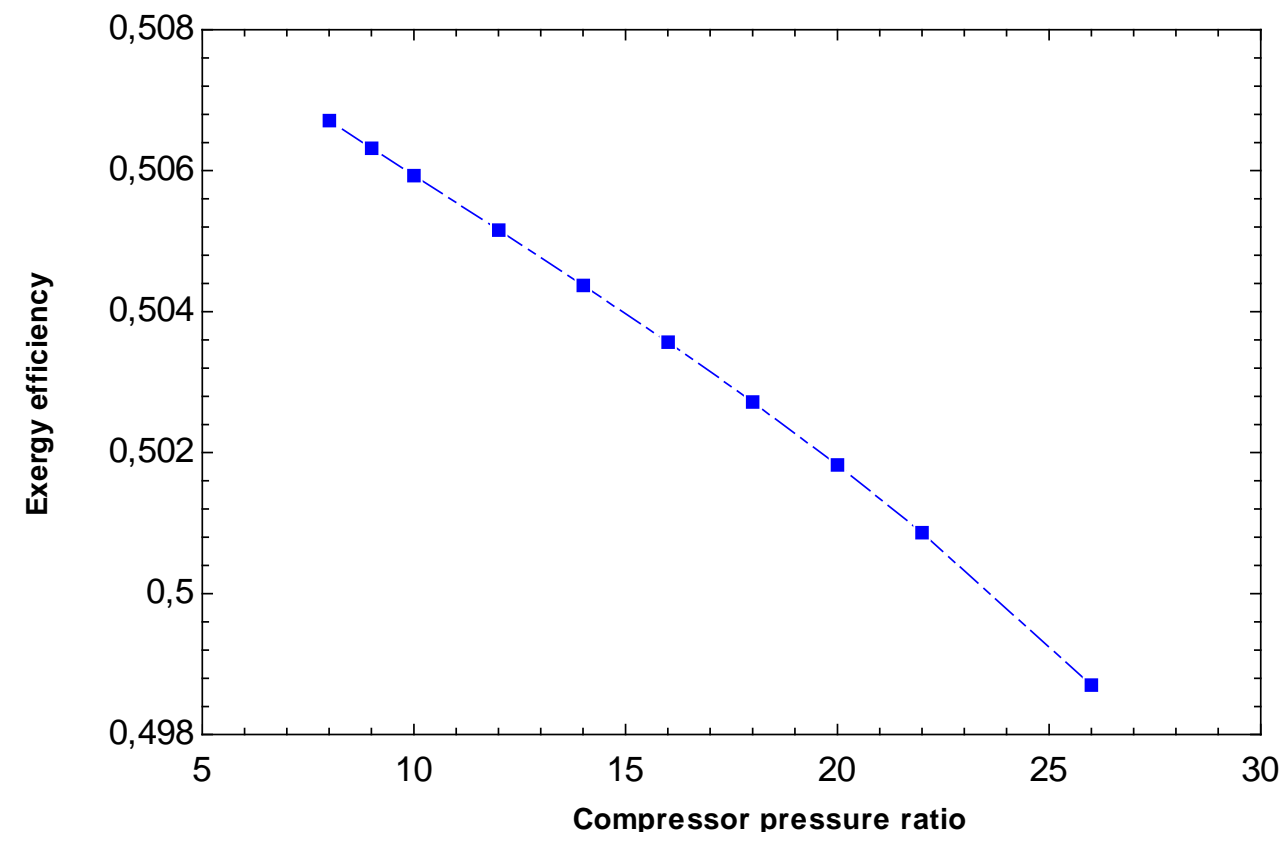

Figure 3. Effect of the air compressor pressure ratio variation on the exergy efficiency 
The second sensitive parameter of the proposed energy system is gas turbine inlet temperature. The exergy efficiency for different values of gas turbine inlet temperature is illustrated in Figure 4. As it is shown, they have a direct relationship with one another. There is a constant rise in the exergy efficiency when this temperature is increased. In the other word, as far as gas turbine inlet temperature increases, the amount of exergy efficiency increase. There is a logical explanation for this event. Whatever the temperature of the inlet gas turbine increase, the enthalpy, and entropy of the feed stream of the gas turbine is increased and more thermal energy is converted to the power. So, based on the basic description of exergy concept, efficiency of that element is improved. The optimum point for this case is $\mathrm{T}_{3}=692 \mathrm{~K}$, and exergy efficiency is equal to $52.51 \%$.

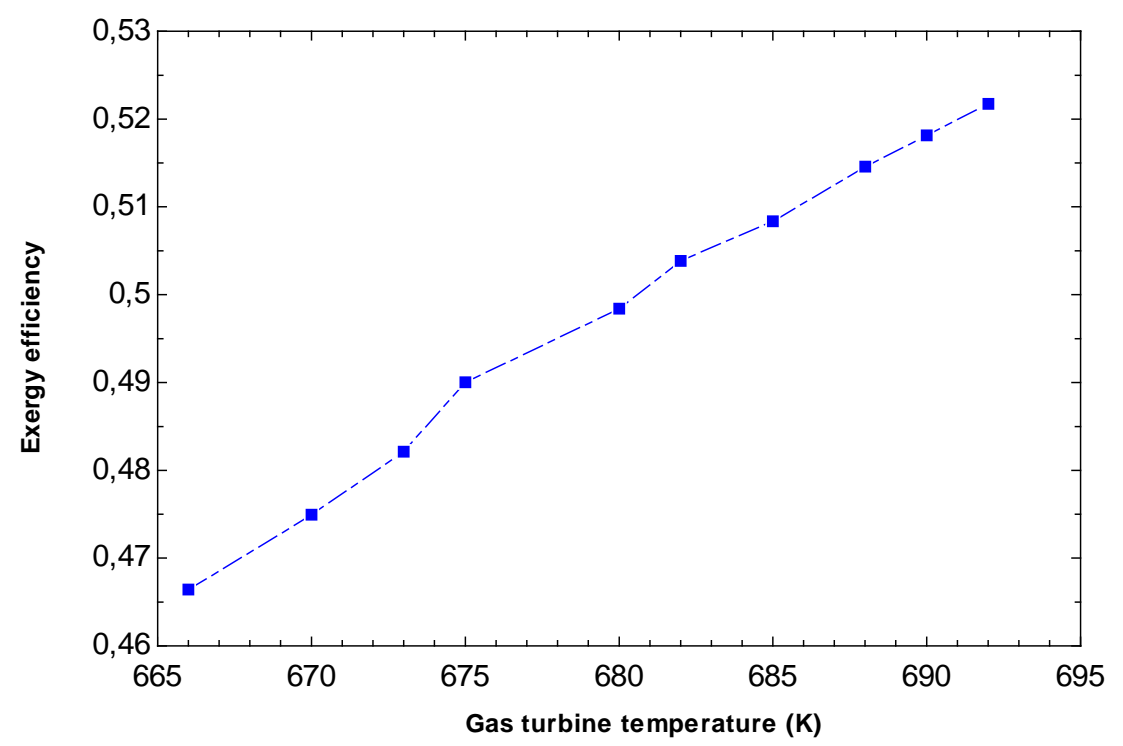

Figure 4. Effect of the gas turbine inlet temperature on the exergy efficiency

The third sensitive parameter of the aimed energy system is combustor inlet temperature. The performance of cycle at different combustor inlet temperature is shown graphically in Figure 5. It can be figured out that when combustor inlet temperature increases from $630 \mathrm{~K}$ to $670 \mathrm{~K}$, the exergy efficiency decreases from $52.7 \%$ to $48.3 \%$. As it is mentioned before the difference between two sources of temperature is one of the main reasons of exergy destruction and increasing in exergy destruction leads the system to poor performance in exergy efficiency. This figure shows that to obtain the highest exergy efficiency of aimed energy system the combustor inlet temperature must set on the minimum range at acceptable temperature.

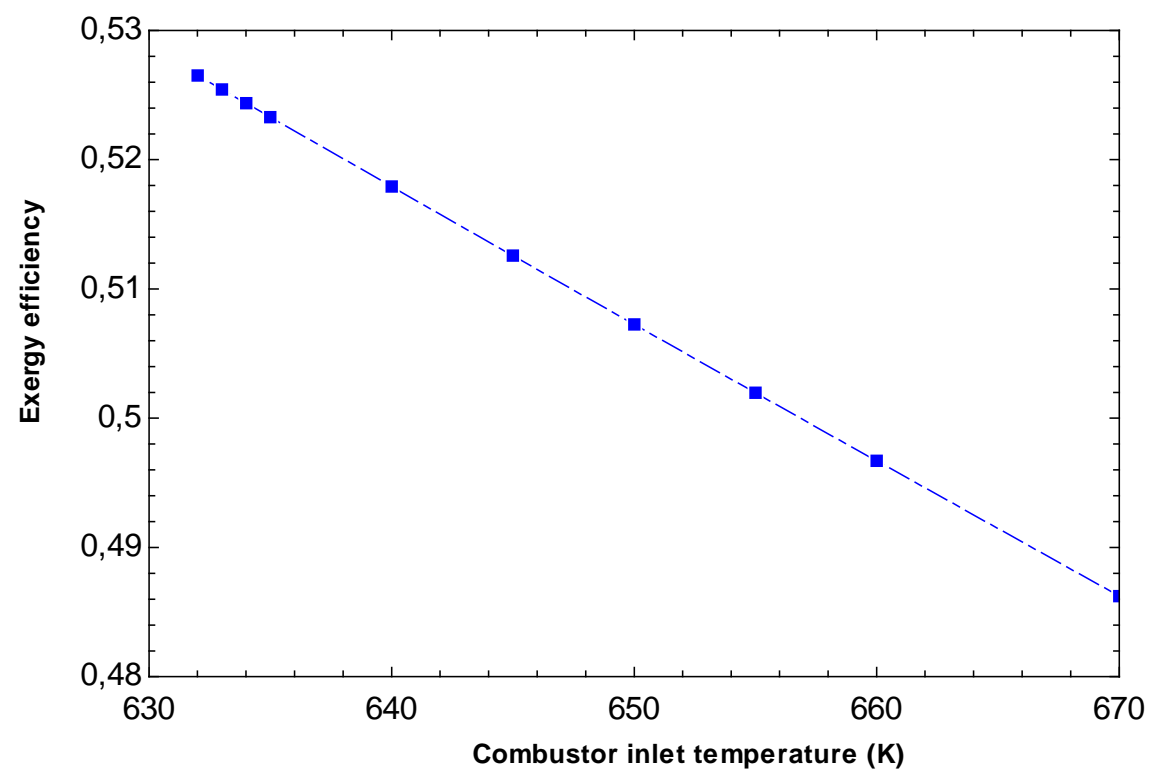

Figure 5. Effect of the combustor inlet temperature on the exergy efficiency 
In Figure 6, the effect of gasifier inlet steam temperature on the exergy efficiency is examined. This parameter was detected as another sensitive parameter of the suggested cycle. As it is extracted from this figure, there is two section of the figure. In the one part of that, the slope of the figure is sharp, and exergy efficiency of the aimed system is decreased. In another part of the figure the slope of the figure is slowed down and in exergy efficiency of the system is decreased with the more average slope. Also one of the common ways of improving the performance of a thermal energy system is increasment in the input temperatures, in some cases, thermal irreversibility is increased and it leads the system to the worse efficiency condition. So based on the clear trend of the Fig6, at the minimum acceptable gasifier inlet temperature, the system shows the highest exergy efficiency. As can be seen on the figure, the slope of changes between $600 \mathrm{~K}$ to $891 \mathrm{~K}$ is much more than $891 \mathrm{~K}$ to $1200 \mathrm{~K}$. So, the optimum point is $600 \mathrm{~K}$.

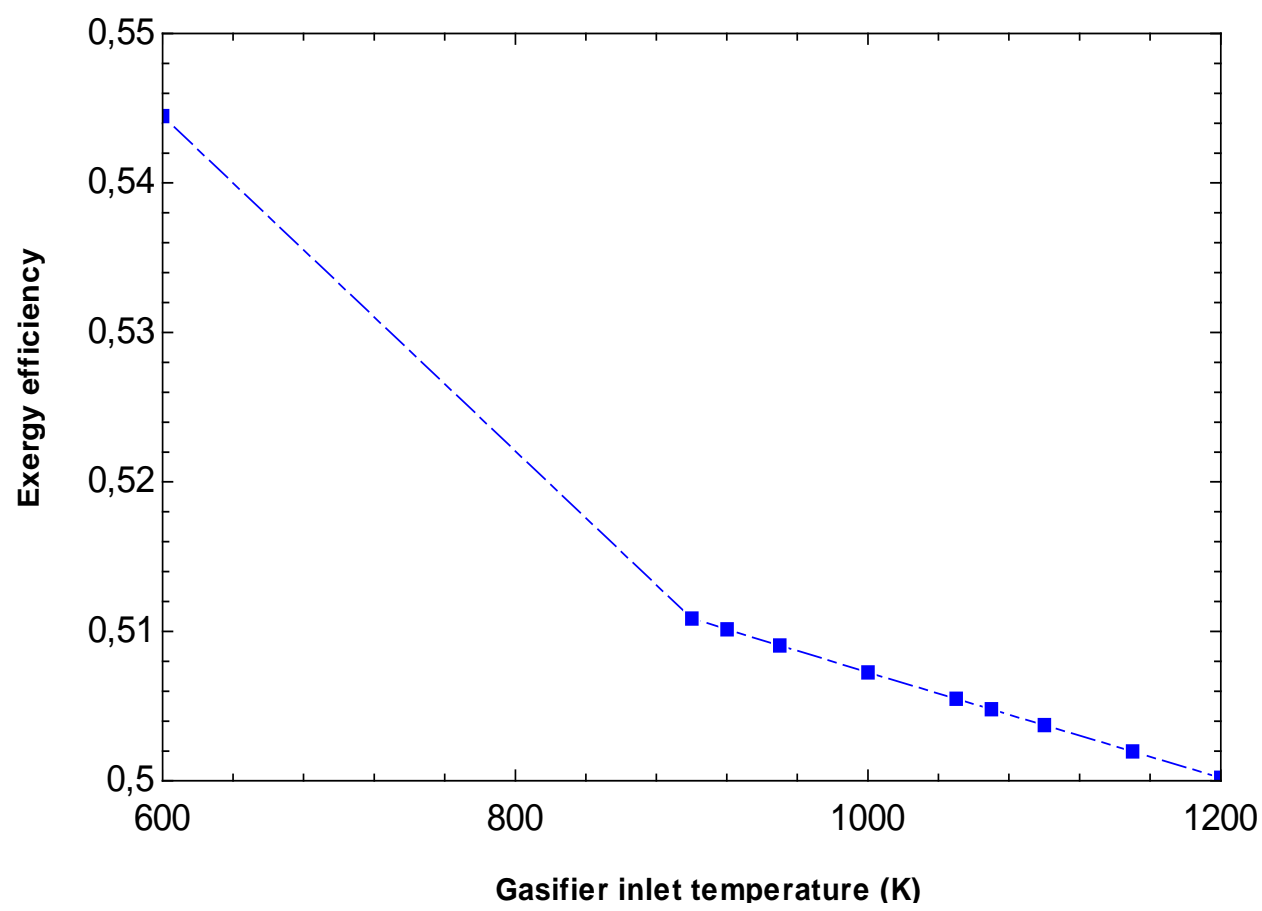

Figure 6. Effect of the gasifier inlet temperature on the exergy efficiency

As presented in Table 7, exergy efficiency increases $4.4 \%$ in comparison to base case value. This optimize point extracted from single objective optimization by genetic algorithm in the EES software. The decision variables based on sensitive analyses are changed to reach the best overall exergy efficiency. In fact, improving exergy efficiency is the final goal of the optimization process. The thing that needs to be highlighted here is that the weight of parameters in this optimization was consumed equally. Moreover, the ideal case for decision variables is extracted after optimization of the trigeneration system.

Table 7. Optimum values of decision variables and objective functions for single objective optimization

\begin{tabular}{|l|c|c|}
\hline \multicolumn{1}{|c|}{ Parameters } & Base case & Ideal case \\
\hline Exergy Efficiency (\%) & 52 & 54.3 \\
\hline Gas turbine inlet temperature(K) & 650 & 692 \\
\hline air compressor pressure ratio variation & 8 & 6.5 \\
\hline Combustor inlet temperature(K) & 609 & 600 \\
\hline gasifier inlet temperature(K) & 600 & 600 \\
\hline
\end{tabular}




\section{CONCLUSION}

In this study, energetic evaluation and optimization have been carried out for an $11.2 \mathrm{~kW}$ output work. The exergy of all components has been defined, and the energetic efficiency of each component has been evaluated. Based on the results of the current study, it can be concluded that the most significant percentage of the exergy destructions is associated with the gasifier, compressor, and combustor respectively. Furthermore, the amount of these percentages are $47 \%, 26.3 \%$, and $14 \%$. These destructions are caused by internal and external irreversible processes including combustion, chemical reactions, phase change and high temperature difference between two parts in the gasifier, compressor, and combustor, so it causes total incoming exergy destruction by syngas energy and absorbed radiation from the solar collector.

The net generating electric power, cooling load, heating load are reported to be $11.2 \mathrm{~kW}, 15.3 \mathrm{~kW}$, and $17.4 \mathrm{~kW}$ respectively. The values of optimum exergy efficiency as the output of running the Genetic Algorithm for single-objective optimization problem reached $4 \%$.

The optimization code developed shows that exergy efficiency improved significantly for optimum operation and we can save a significant amount of energies through a dynamic optimization of the system. The following remarks can be extracted from this study:

- Exegetic efficiency has a linear and remarkable increase via gas turbine inlet temperature.

- By increasing gasifier inlet steam temperature, compressor pressure ratio, and combustor inlet temperature, energetic efficiency of the cycle are increased.

- Increasing the gasifier inlet temperature, compressor pressure ratio, and combustor inlet temperature will increase exergy destruction significantly.

\section{NOMENCLATURE}

\begin{tabular}{|c|c|}
\hline $\mathrm{T}$ & Temperature \\
\hline $\mathrm{P}$ & Pressure \\
\hline $\mathrm{S}$ & Entropy \\
\hline $\mathrm{S}_{0}$ & Entropy \\
\hline $\mathrm{h}$ & Enthalpy of reference state \\
\hline h & Hour \\
\hline$h_{0}$ & Enthalpy of reference state \\
\hline$\dot{m}$ & Mas flow rate \\
\hline KW & Kilowatt \\
\hline MW & Megawatt \\
\hline $\mathrm{T}_{0}$ & The temperature of reference state \\
\hline $\mathrm{P}_{0}$ & The pressure of reference state \\
\hline$T_{\text {evap }}$ & Temperature of evaporator \\
\hline $\mathrm{F}_{\mathrm{R}}$ & Removal factor \\
\hline$A_{r}$ & Receiver area \\
\hline $\mathrm{U}_{\mathrm{L}}$ & Solar collector overall heat loss efficiency \\
\hline $\mathrm{S}$ & Heat absorbed by the receiver \\
\hline$A_{\text {Coll }}$ & Collector area \\
\hline $\mathrm{G}_{\mathrm{t}}$ & Solar radiation flux on the plane of the solar collector \\
\hline ORC & Organic Rankine cycle \\
\hline LHV & Low heating value \\
\hline $\mathrm{Li}-\mathrm{Br}$ & Litume bromide \\
\hline PTC & Parabolic Trough solar collector \\
\hline EES & Engineering equation solver \\
\hline $\mathrm{X}_{\mathrm{D}}$ & Exergy destruction \\
\hline
\end{tabular}




$\begin{array}{ll}X^{C h} & \text { Chemical exergy } \\ \dot{E} x^{c h} & \text { Chemical exergy rate } \\ \dot{E} X_{D} & \text { Exergy destruction rate } \\ \dot{E} x^{p h}{ }_{k} & \text { Physical exergy rate of } \mathrm{k} \\ X_{k} & \text { The mole fraction of } \mathrm{k} \\ e x_{c h}^{k} & \text { Chemical exergy of } \mathrm{k} \\ \mathrm{R}_{E_{s}} & \text { universal gas constant } \\ \dot{Q}_{K} & \text { Exergy rate of sun } \\ T_{k} & \text { Heat flow rate of } \mathrm{k} \\ C_{p} & \text { Temperature of } \mathrm{k}\end{array}$

$\mathrm{A}_{\mathrm{a}} \quad$ Aperture area

$\dot{E} X_{\text {PTC }} \quad$ Exergy rate of parabolic trough solar collector

$T_{s} \quad$ The temperature of the sun surface

$\dot{W}_{\text {Turb }} \quad$ The work rate of the turbine

$\dot{W}_{\text {is,Turb }}$ The isentropic work rate of turbine

$\dot{E} x_{D, T u r b} \quad$ Exergy destruction rate of the turbine

$\dot{W}_{\text {Pump1 }} \quad$ The work rate of pump1

$E_{\text {Evap } \quad \text { Energy of evaporator }}$

$\dot{E} X_{\text {Evap }} \quad$ Exergy rate of evaporator

$\dot{E} x_{D, H} \quad$ Exergy destruction rate of heater

$\dot{E} X_{D, \text { Evap }} \quad$ Exergy destruction rate of evaporator1

$\dot{E} x_{S} \quad$ Exergy rate of sun radiation

$\dot{W}_{c} \quad$ Work flow rate of the compressor

$X_{q, k} \quad$ Heat exergy of $\mathrm{k}$

$\eta_{\text {en }} \quad$ The thermal efficiency of the system

$\dot{E}_{\text {Output }} \quad$ Output energy rate

$\dot{E}_{\text {Input } \quad \text { Input energy rate }}$

$\dot{E}_{\text {Evap }} \quad$ Energy rate of evaporator

$\dot{E} x_{p} \quad$ Exergy rate of product

$\dot{E} x_{f} \quad$ Exergy rate of fuel

$\dot{W}_{\text {Network }}$ The work rate of the network

$\eta_{\text {Gen }} \quad$ Efficiency of generator 


$\begin{array}{ll}\Delta T_{\text {evap }} & \text { Temperature difference of evaporator } \\ T_{\text {evap }} & \text { Temperature of evaporator } \\ \text { GA } & \text { Genetic algorithm } \\ \text { ex } & \text { Exergy } \\ \text { Ex } & \text { Exergy } \\ \text { Evap } & \text { Evaporator } \\ \text { Coll } & \text { Collector } \\ \text { Comp } & \text { Compressor } \\ \text { Elec } & \text { Electric } \\ \text { E.G } & \text { Electric generation } \\ \text { CHP } & \text { Combined heating and power plant } \\ \text { CCHP } & \text { Combined cooling heating and power plant } \\ \text { MCFC } & \text { Molten carbonate fuel cell }\end{array}$

\section{REFERENCES}

[1] Lenz GE. Process engineering and design for air pollution control. Waste Manag 1994. https://doi.org/10.1016/0956-053x(94)90061-2.

[2] Lee U, Chung JN, Ingley HA. High-temperature steam gasification of municipal solid waste, rubber, plastic and wood. Energy and Fuels, 2014. https://doi.org/10.1021/ef500713j.

[3] Vera D, Jurado F, Panopoulos KD, Grammelis P. Modelling of biomass gasifier and microturbine for the olive oil industry. Int J Energy Res 2012. https://doi.org/10.1002/er.1802.

[4] Dai Y, Wang J, Gao L. Exergy analysis, parametric analysis and optimization for a novel combined power and ejector refrigeration cycle. Appl Therm 2009. https://doi.org/10.1016/j.applthermaleng.2008.09.016.

[5] Mago PJ, Chamra LM. Analysis and optimization of CCHP systems based on energy, economical, and environmental considerations. Energy Build 2009. https://doi.org/10.1016/j.enbuild.2009.05.014.

[6] Klein SA. Engineering Equation Solver for Microsoft Windows Operating Systems. F-Chart Softw 2011.

[7] Laurence LC, Ashenafi D. Syngas treatment unit for small scale gasification - Application to IC engine gas quality requirement. J Appl Fluid Mech 2012. https://doi.org/10.36884/jafm.5.01.11963.

[8] Campo P, Benitez T, Lee U, Chung JN. Modeling of a biomass high temperature steam gasifier integrated with assisted solar energy and a micro gas turbine. Energy Convers Manag 2015. https://doi.org/10.1016/j.enconman.2014.12.069.

[9] Al-Sulaiman FA, Dincer I, Hamdullahpur F. Exergy modeling of a new solar driven trigeneration system. Sol Energy 2011. https://doi.org/10.1016/j.solener.2011.06.009.

[10] Wang JJ, Yang K, Xu ZL, Fu C. Energy and exergy analyses of an integrated CCHP system with biomass air gasification. Appl Energy 2015. https://doi.org/10.1016/j.apenergy.2014.12.085.

[11] Huicochea A, Rivera W, Gutiérrez-Urueta G, Bruno JC, Coronas A. Thermodynamic analysis of a trigeneration system consisting of a micro gas turbine and a double effect absorption chiller. Appl Therm Eng 2011. https://doi.org/10.1016/j.applthermaleng.2011.06.016.

[12] Doseva N, Chakyrova D. Energy and exergy analysis of cogeneration system with biogas engines. J Therm Eng 2015. https://doi.org/10.18186/jte.75021.

[13] Moharamian A, Soltani S, Rosen MA, Mahmoudi SMS, Morosuk T. A comparative thermoeconomic evaluation of three biomass and biomass-natural gas fired combined cycles using organic Rankine cycles. J Clean Prod 2017. https://doi.org/10.1016/j.jclepro.2017.05.174.

[14] Koroglu T, Sogut OS. Advanced exergy analysis of an Organic rankine cycle waste heat recovery system of a marine power plant. J Therm Eng 2017. https://doi.org/10.18186/thermal.298614.

[15] Ghasemi A, Hashemian N, Noorpoor A, Heidarnejad P. Exergy based optimization of a biomass and solar fuelled cchp hybrid seawater desalination plant. J Therm Eng 2017. 
https://doi.org/10.18186/thermal.290251.

[16] Mehrpooya M, Sayyad S, Zonouz MJ. Energy, exergy and sensitivity analyses of a hybrid combined cooling, heating and power (CCHP) plant with molten carbonate fuel cell (MCFC) and Stirling engine. J Clean Prod 2017. https://doi.org/10.1016/j.jclepro.2017.01.157.

[17] Ghasemi A, Heidarnejad P, Noorpoor A. A novel solar-biomass based multi-generation energy system including water desalination and liquefaction of natural gas system: Thermodynamic and thermoeconomic optimization. J Clean Prod 2018. https://doi.org/10.1016/j.jclepro.2018.05.160.

[18] Çengel Y a. Thermodynamics: An Engineering Approach. McGraw-Hill 2004.

[19] Golkar B, Naserabad SN, Soleimany F, Dodange M, Ghasemi A, Mokhtari H, et al. Determination of optimum hybrid cooling wet/dry parameters and control system in off design condition: Case study. Appl Therm Eng 2019;149:132-50. https://doi.org/10.1016/j.applthermaleng.2018.12.017.

[20] Kalogirou SA. Solar Energy Engineering: Processes and Systems. 2009.

[21] Cao Y, Nikafshan Rad H, Hamedi Jamali D, Hashemian N, Ghasemi A. A novel multi-objective spiral optimization algorithm for an innovative solar/biomass-based multi-generation energy system: 3E analyses, and optimization algorithms comparison. Energy Convers Manag 2020;219:112961. https://doi.org/10.1016/j.enconman.2020.112961.

[22] Seshadri K. Thermal design and optimization. vol. 21. 1996. https://doi.org/10.1016/s03605442(96)90000-6.

[23] Prins MJ. Thermodynamic analysis of biomass gasification and torrefaction. 2005. https://doi.org/10.6100/IR583729.

[24] Dincer I, Cengel YA. Energy, entropy and exergy concepts and their roles in thermal engineering. Entropy 2001. https://doi.org/10.3390/e3030116.

[25] Noorpoor A, Heidarnejad P, Hashemian N, Ghasemi A. A thermodynamic model for exergetic performance and optimization of a solar and biomass-fuelled multigeneration system. Energy Equip Syst 2016. https://doi.org/10.22059/ees.2016.23044.

[26] Saltelli A, Tarantola S, Campolongo F. Sensitivity analysis as an ingredient of modeling. Stat Sci 2000. https://doi.org/10.1214/ss/1009213004.

[27] Shayesteh AA, Koohshekan O, Ghasemi A, Nemati M, Mokhtari H. Determination of the ORC-RO system optimum parameters based on 4E analysis; Water-Energy-Environment nexus. Energy Convers Manag 2019;183:772-90. https://doi.org/10.1016/j.enconman.2018.12.119.

[28] Baghernejad A, Yaghoubi M. Exergoeconomic analysis and optimization of an Integrated Solar Combined Cycle System (ISCCS) using genetic algorithm. Energy Convers Manag 2011. https://doi.org/10.1016/j.enconman.2010.12.019.

[29] Mozafari A, Ahmadi A, Ehyaei MA. Optimisation of micro gas turbine by exergy, economic and environmental (3E) analysis. Int J Exergy 2010. https://doi.org/10.1504/IJEX.2010.029611.

[30] Ameri M, Ahmadi P, Khanmohammadi S. Exergy analysis of a 420 MW combined cycle power plant. Int J Energy Res 2008. https://doi.org/10.1002/er.1351. 